\title{
Complete Genome Sequence of Indian Race 4 of Xanthomonas oryzae pv. oryzae, the Causal Agent of Bacterial Blight of Rice
}

Kalyan K. Mondal, ${ }^{\dagger}$ Geeta Verma, Aditya Kulshreshtha, Yuvika Rajrana, Chandra Mani, Madhvi Soni, Kishorekumar Reddy, Thungri Ghoshal, Amrutha Lakshmi, and Kalaivanan NS

Plant Bacteriology Lab, ICAR-Indian Agricultural Research Institute, Pusa Campus, New Delhi 110012, India

\begin{abstract}
Xanthomonas oryzae pv. oryzae, the causal bacterium of bacterial blight limits rice production globally. Currently, genome sequences for only a few $X$. oryzae pv. oryzae isolates are available from India. Based on the next-generation sequencing and single-molecule sequencing in real-time technologies, we present here the complete genome sequence of $X$. oryzae pv. oryzae race 4 , a highly virulent member of the Indian $X$. oryzae pv. oryzae population that has been extensively used in different research studies. The genome data will contribute to our understanding of $X$. oryzae pv. oryzae genomic features and pave the way for research on rice- $X$. oryzae pv. oryzae interactions.
\end{abstract}

Xanthomonas oryzae pv. oryzae causes bacterial blight (BB) that constitutes a major biotic threat to rice production worldwide. In India, the disease appears every year and causes substantial loss to rice production (Mondal 2016). More than $40 \mathrm{Xa}$ (resistance $[R]$ ) genes are identified in rice but $X$. oryzae pv. oryzae still manages to bypass the rice immune response. The breakdown of rice resistance is mainly due to the emergence of new virulent races of $X$. oryzae pv. oryzae at periodic intervals. The diversity in the $X$. oryzae pv. oryzae population is well documented by many workers and there are over 30 races reported from several countries. The ever-changing $X$. oryzae pv. oryzae races was described by researchers from India as well (Adhikari et al. 1999; Mishra et al. 2013; Mondal et al. 2014; Yugander et al. 2017). From the northwestern and northeastern parts of India, the $X$. oryzae pv. oryzae population was pathotyped into six races based on reactions to single as well as combinations of $R$ genes in rice (Mondal et al. 2014). Race 4 (strain ITCCBB0002) is a predominant and most virulent member among six races. Race 4 has been extensively used during phenotyping for resistance breeding program (Ellur et al. 2016a,b) as well as for genetic screening of its type 3 secretion system (T3SS) effectors (Mondal et al. 2014). Phytopathogenic Xanthomonas spp. utilize T3SS effectors to suppress plant innate immunity (Kumar et al. 2016; Soni and Mondal 2018). T3SS effectors are of two types; namely, transcription activator like (TAL) and non-TAL or Xanthomonas outer protein (Xop) effectors (White et al. 2009). $X$. oryzae pv. oryzae race 4 possesses $18 \mathrm{TAL}$ and 21 Xop effectors (Mondal et al. 2014). Detailed investigation revealed that XopF and XopR are two crucial effectors of race 4 that contribute to the development of BB in rice (Mondal et al. 2016; Verma et al. 2018, 2019). In order to have detailed insight into the genomic features of race 4, in the present study, we generated a whole-genome sequence using the PacBio (Pacific Biosciences Inc., Menlo

${ }^{\dagger}$ Corresponding author: K. K. Mondal; mondaliari@gmail.com

The author(s) declare no conflict of interest.

Accepted for publication 8 January 2020 .

(C) 2020 The American Phytopathological Society
Funding

Support was provided by the Department of Biotechnology, Ministry of Science and Technology grant numbers BT/PR15179/AGIII/103/903/ 2015 and BT/PR16238/NER/95/103/ 2015.

\section{Keywords}

effectors, genome, genomics, rice, type-3 secretion,

Xanthomonas oryzae pv. oryzae 
Table 1. Comparative accounts on genomic features of Indian Xanthomonas oryzae pv. oryzae race 4 with other Asian strains

\begin{tabular}{lllll} 
& \multicolumn{4}{c}{ Asian $\boldsymbol{X}$. oryzae pv. oryzae strains } \\
\cline { 2 - 5 } Genomic features & Indian race 4 & Korean KACC10331 & Philippines PXO99A & Japanese MAFF311018 \\
Accession number & CP046148 & NC_006834 & NC_010717 & NC_007705 \\
Length (bp) & 4731568 & 4941439 & 5238555 & 4940217 \\
G + C content (\%) & 63.8 & 63.7 & 63.6 & 63.7 \\
Total genes & 4,505 & 4,939 & 4,899 & 4,663 \\
Total protein coding genes (CDS) & 4,299 & 4,734 & 4,688 & 4,457 \\
CDS encoding protein with assigned function & 3,542 & 3,721 & 3,944 & 3,757 \\
CDS encoding hypothetical protein & 757 & 1,013 & 744 & 700 \\
Noncoding RNAs & 143 & 146 & 151 & 147 \\
Transfer RNA & 57 & 54 & 2 & 53 \\
Ribosomal RNA operons & 2 & 2 & 0 & 2 \\
Plasmids & 0 & 0 & Salzberg et al. 2008 & Ochiai et al. 2005 \\
Reference & This study & Lee et al. 2005 & & \\
\hline
\end{tabular}

Park, CA, U.S.A.) sequencing method. This genome information would certainly help researchers to further decipher the $X$. oryzae pv. oryzae-rice interaction with reference to virulent race 4 and, thereby, would provide scope in exploring a new management strategy for BB.

Total genomic DNA was extracted and completely sequenced using the PacBio platform. In total, 16,482 polymerase reads were obtained, encompassing of $547.7 \mathrm{Mbp}$. The de novo assembly was performed using Canu, version 1.5 (Koren et al. 2017) and the total protein coding genes (CDS) were predicted using Glimmer, version 3. The final genome assembly was composed of $4,731,568 \mathrm{bp}$ and had a total of $63.8 \% \mathrm{GC}$ content. There were 4,505 genes, 4,299 CDS, and 3,542 protein coding genes. Among the total 206 RNA encoding genes, 6 genes encoded for ribosomal RNAs, 57 encoded for transfer RNAs, and 143 were identified as noncoding RNAs. A comparative account on genomic features of Indian $X$. oryzae pv. oryzae race 4 with other Asian $X$. oryzae pv. oryzae strains, including Korean strain KACC10331, Philippines strain PXO99A, and Japanese strain MAFF311018, was determined (Table 1). This whole-genome shotgun project has been deposited in the GenBank database under accession number CP046148.

\section{Literature Cited}

Adhikari, T. B., Basnyat, R. C., and Mew, T. W. 1999. Virulence of Xanthomonas oryzae pv. oryzae on rice lines containing single resistance genes and gene combinations. Plant Dis. 83:46-50.

Ellur, R. K., Khanna, A., Gopala Krishnan, S., Bhowmick, P. K., Vinod, K. K., Nagarajan, M., Mondal, K. K., Singh, N. K., Singh, K., Prabhu, K. V., and Singh, A. K. 2016a. Marker-aided incorporation of Xa38, a novel bacterial blight resistance gene, in PB1121 and comparison of its resistance spectrum with xa13+ Xa21. Sci. Rep. 6:29188.

Ellur, R. K., Khanna, A., Yadav, A., Pathania, S., Rajashekara, H., Singh, V. K., Gopala Krishnan, S., Bhowmick, P. K., Nagarajan, M., Vinod, K. K., Prakash, G., Mondal, K. K., Singh, N. K., Vinod Prabhu, K., and Singh, A. K. 2016b. Improvement of Basmati rice varieties for resistance to blast and bacterial blight diseases using marker assisted backcross breeding. Plant Sci. 242: 330-341.

Koren, S., Walenz, B. P., Berlin, K., Miller, J. R., Bergman, N. H., and Phillippy, A. M. 2017. Canu: Scalable and accurate long-read assembly via adaptive $k$-mer weighting and repeat separation. Genome Res. 27:722-736.

Kumar, R., Soni, M., and Mondal, K. K. 2016. XopN-T3SS effector of Xanthomonas axonopodis pv. punicae localizes to the plasma membrane and modulates ROS accumulation events during blight pathogenesis in pomegranate. Microbiol. Res. 193:111-120.

Lee, B. M., Park, Y. J., Park, D. S., Kang, H. W., Kim, J. G., Song, E. S., Park, I. C., Yoon, U. H., Hahn, J. H., Koo, B. S., Lee, G. B., Kim, H., Park, H. S., Yoon, K. O., Kim, J. H., Jung, C. H., Koh, N. H., Seo, J. S., and Go, S. J. 2005. The genome sequence of Xanthomonas oryzae pathovar oryzae KACC10331, the bacterial blight pathogen of rice. Nucleic Acids Res. 33:577-586.
Mishra, D., Vishnupriya, M. R., Anil, M. G., Konda, K., Raj, Y., and Sonti, R. V. 2013. Pathotype and genetic diversity amongst Indian isolates of Xanthomonas oryzae pv. oryzae. PLoS One 8:e81996.

Mondal, K. K. 2016. Emerging phytobacterial diseases in India: Research status and challenges. Pages 167-178 in: Perspectives of Plant Pathology in Genomic Era. P. Chowdappa, P. Sharma, D. Singh, and A. K. Misra, eds. India Phytopathological Society, New Delhi, India.

Mondal, K. K., Meena, B. R., Junaid, A., Verma, G., Mani, C., Majumder, D., Khicher, M., Kumar, S., and Banik, S. 2014. Pathotyping and genetic screening of type III effectors in Indian strains of Xanthomonas oryzae pv. oryzae causing bacterial leaf blight of rice. Physiol. Mol. Plant Pathol. 86:98-106.

Mondal, K. K., Verma, G., Manju, Junaid, A., and Mani, C. 2016. Rice pathogen Xanthomonas oryzae pv. oryzae employs inducible hrp-dependent XopF type III effector protein for its growth, pathogenicity and for suppression of PTI response to induce blight disease. Eur. J. Plant Pathol. 144:311-323.

Ochiai, H., Inoue, Y., Takeya, M., Sasaki, A., and Kaku, H. 2005. Genome sequence of Xanthomonas oryzae pv. oryzae suggests contribution of large numbers of effector genes and insertion sequences to its race diversity. JARQ 39:275-287.

Salzberg, S. L., Sommer, D. D., Schatz, M. C., Phillippy, A. M., Rabinowicz, P. D., Tsuge, S., Furutani, A., Ochiai, H., Delcher, A. L., Kelley, D., Madupu, R., Puiu, D., Radune, D., Shumway, M., Trapnell, C., Aparna, G., Jha, G., Pandey, A., Patil, P. B., Ishihara, H., Meyer, D. F., Szurek, B., Verdier, V., Koebnik, R., Dow, J. M., Ryan, R. P., Hirata, H., Tsuyumu, S., Won Lee, S., Seo, Y. S., Sriariyanum, M., Ronald, P. C., Sonti, R. V., Van Sluys, M. A., Leach, J. E., White, F. F., and Bogdanove, A. J. 2008. Genome sequence and rapid evolution of the rice pathogen Xanthomonas oryzae pv. oryzae PXO99A. BMC Genomics 9:204. 
Soni, M., and Mondal, K. K. 2018. Xanthomonas axonopodis pv. punicae uses XopL effector to suppress pomegranate immunity. J. Integr. Plant Biol. 60:341-357.

Verma, G., Mondal, K.K., Kulshreshtha. A. and Sharma, M. 2019. XopR T3SSeffector of Xanthomonas oryzae pv. oryzae suppresses cell death-mediated plant defense response during bacterial blight development in rice. 3 Biotech 9: 272. doi:10.1007/s13205-019-1802-9

Verma, G., Sharma, M., and Mondal, K. K. 2018. XopR TTSS-effector regulates in planta growth, virulence of Indian strain of Xanthomonas oryzae pv. oryzae via suppressing reactive oxygen species production and cell wall-associated rice immune responses during blight induction. Funct. Plant Biol. 45:561-574.

White, F. F., Potnis, N., Jones, J. B., and Koebnik, R. 2009. The type III effectors of Xanthomonas. Mol. Plant Pathol. 10:749-766.

Yugander, A., Sundaram, A. M., Ladhalakshmi, D., Hajira, S. K., Prakasam, V., Prasad, M. S., Sheshu Madhav, M., Ravindra Babu, V., and Laha, G. S. 2017. Virulence profiling of Xanthomonas oryzae pv. oryzae isolates, causing bacterial blight of rice in India. Eur. J. Plant Pathol. 149:171-191. 